\title{
BAKUNIN AND THE UNITED STATES
}

"MIKHAIL ALEKSANDROVICH BAKUNIN is in San Francisco",
announced the front page of Herzen's Kolokol in November 1861. "HE IS FREE! Bakunin left Siberia via Japan and is on his way to England. We joyfully bring this news to all Bakunin's friends." ${ }^{1}$ Arrested in Chemnitz in May 1849, Bakunin had been extradited to Russia in 1851 and, after six years in the Peter-Paul and Schlüsselburg fortresses, condemned to perpetual banishment in Siberia. On June 17, 1861, however, he began his dramatic escape. Setting out from Irkutsk, he sailed down the Amur to Nikolaevsk, where he boarded a government vessel plying the Siberian coast. Once at sea, he transferred to an American sailing ship, the Vickery, which was trading in Japanese ports, and reached Japan on August 16th. A month later, on September 17th, he sailed from Yokohama on another American vessel, the Carrington, bound for San Francisco. ${ }^{2} \mathrm{He}$ arrived four weeks later, ${ }^{3}$ completing, in Herzen's description, "the very longest escape in a geographical sense". 4

Bakunin was forty-seven years old. He had spent the past twelve years in prison and exile, and only fourteen years of life - extremely active life, to be sure - lay before him. He had returned like a ghost from the past, "risen from the dead" as he wrote to Herzen and Ogarev from San Francisco. ${ }^{5} \mathrm{His}$ sojourn in America, one of the least well-known episodes of his career, lasted two months, from October 15th, when he landed in San Francisco, to

1 Kolokol (London), November 22, 1861. All dates are new style.

2 See E. H. Carr, "Bakunin's Escape from Siberia", in: The Slavonic Review, XV (1936-37), pp. 377-88; Libero International (Kobe), No 5 (1978). In Yokohama, by an odd coincidence, Bakunin ran into Wilhelm Heine, a fellow participant in the Dresden rising of 1849 .

${ }^{3}$ San Francisco Evening Bulletin. October 16, 1861.

4 Alexander Herzen, My Past and Thoughts, transl. by Constance Garnett (6 vols; London, 1924-27), V, p. 137.

5 Pis'ma M. A. Bakunina k A. I. Gertsenu iN. P. Ogarevu, ed. by M. P. Dragomanov (St Petersburg, 1906), p. 191. 
December 14th, when he left New York for Liverpool and London. As far as the sources permit, the present article will describe this interlude - the places he visited, the people he met, the impression he made on them. It will also explore his attitude towards the United States, both during and after his visit, and trace his influence on the American Anarchist movement over the last hundred years.

When Bakunin reached San Francisco, he wrote immediately to Herzen and Ogarev in London. First and foremost, he asked that $\$ 500$ be sent to New York to enable him to proceed to England. For his passage to New York he had already borrowed $\$ 250$ from F. P. Coe, a young English clergyman whom he had met on the Carrington. His own funds, he wrote, were exhausted, and he had "no friends, nor even acquaintances" in San Francisco, so that, "had I not found a kind person who gave me a 250 dollar loan to New York, I should have been in great difficulty". 6 Bakunin begged Herzen and Ogarev to get word of his escape to his family in Tver province. Expecting his wife to join him when she heard the news, he asked his friends to find them an "inexpensive nook" (deshevyi ugolok) in their neighborhood. ${ }^{7}$

It was Bakunin's intention, on reaching London, to resume his revolutionary activities. Like a man awakened from a trance, as $\mathrm{E}$. $\mathrm{H}$. Carr has noted, Bakunin was determined to take up life again at the point where he had laid it down a dozen years before. As Herzen put it, "the fantasies and ideals with which he was imprisoned in Königstein in 1849 he had preserved complete and carried across Japan and California in 1861."8 Above all, he would devote himself to the liberation of the Slavic peoples. "Friends", he wrote to Herzen and Ogarev, "I long to come to you with all my being, and as soon as I arrive, I will set to work. I will assist you on the Polish and Slavic question, which has been my idée fixe since 1846 and was my special sphere of activity in 1848 and 1849. The destruction, the total destruction of the Austrian empire will be my last word, I do not say deed that would be too ambitious. To serve this great cause I am ready to become a drummer-boy or even a scoundrel, and if I succeed in advancing it even by a hair's breadth, I shall be satisfied. And after that will come the

6 Bakunin to Herzen and Ogarev, October 15, 1861, ibid., p. 189. Carr gives both $\$ 250$ and $\$ 300$ as the sum borrowed from Rev. Coe: "Bakunin's Escape from Siberia", loc. cit., p. 383, and Michael Bakunin (New York, 1961), p. 247.

7 Pis'ma, p. 189.

8 Carr, Michael Bakunin, op. cit., p. 252; Herzen, My Past and Thoughts, op. cit., V, pp. 131-32. 
glorious free Slavic federation, the one way out for Russia, the Ukraine, Poland, and generally all the Slavic peoples". ${ }^{9}$

On October 21 st, after six days in San Francisco, Bakunin left for New York by way of Panama on the steamship Orizaba. The next day, some 400 miles from the Isthmus, he wrote again to Herzen and Ogarev, repeating his request for money (to be sent to the banking house of Ballin \& Sanders in New York) and inquiring after his family in Russia. ${ }^{10}$ The Orizaba docked in Panama on October 24th. On November 6th, after a delay of two weeks, Bakunin embarked on the Champion bound for New York. ${ }^{11}$ His fellow passengers included the Commander-in-Chief of the Union Army in California, General Sumner, with 430 regulars under Colonel C. S. Merchant. Also on board were three Confederate sympathizers, ex-Senator William M. Gwin of California, Calhoun Benham, a former State Attorney at San Francisco, and Captain J. Brant, the former commander of a revenue cutter. One day out of Panama, General Sumner placed the three under arrest as secessionists conducting business for the South. ${ }^{12}$ In the meantime, Bakunin had struck up an acquaintance with Senator Gwin, who seems to have influenced his views on the Confederacy.

Bakunin arrived in New York on the morning of November $15 \mathrm{th}^{13}$ and registered at Howard House on lower Broadway at Cortlandt Street. Among the people he called on were two old German comrades, Reinhold Solger and Friedrich Kapp, both well-known Forty-eighters. Solger had been educated at Halle and Greifswald, where he received the Ph.D. in 1842 , intending to pursue an academic career in history and philosophy. A Left Hegelian, he was a friend of Arnold Ruge, Ludwig Feuerbach and Georg Herwegh. Solger and Bakunin first met in Zurich in 1843, after which they corresponded for several years, meeting again in Paris in 1847, together with Herzen and Herwegh. ${ }^{14}$ In 1848 Solger joined the revolutionary army in Baden, serving as adjutant to General Mieroslawski, commander of the insurgent forces. When the rising was suppressed, he fled to Switzerland "with a price on his head", emigrating to America in

9 Pis'ma, pp. 189-90; Herzen, My Past and Thoughts, V, p. 131

10 Pis'ma, pp. 191-92.

11 Max Nettlau, Michael Bakunin. Eine Biographie (3 vols; London, 1896-1900), I, pp. 138-40; V. Polonskii, Mikhail Aleksandrovich Bakunin. Zhizn', deiatel'nost', myshlenie, I (Moscow, 1922), pp. 347-48.

12 The New York Times and The New York Tribune, November 16, 1861.

13 The passenger list of the Champion, as printed in The New York Tribune of November 16, 1861, gives his name as "M. Bakonnia".

14 See Bakunin to Solger, October 14, 1844, and Bakunin to Emma Herwegh, October 18 , 1847 , in Sobranie sochinenii i pisem, 1828-1876, ed. by Iu. M. Steklov (4 vols; Moscow, 1934-36), III, pp. 236-38, 267-68. 
1853 and becoming a citizen six years later. A gifted speaker and writer, Solger was twice invited to give the Lowell Institute Lectures in Boston (1857 and 1859) and won two literary prizes, in 1859 for a poem on the centennial of Schiller and in 1862 for a novel on German-American life. An abolitionist and radical Republican, he applied his verbal talents as a campaigner for Abraham Lincoln, who rewarded him with a post in the Treasury Department. He ended his days as a bank director, dying in January 1866 at age of forty-eight. ${ }^{15}$ Like Solger, Friedrich Kapp had known both Bakunin and Herzen in Europe during the 1840's (for a time he was tutor to Herzen's son) ${ }^{16}$ and had been a participant in the 1848 Revolution. Compelled to flee to Geneva, he emigrated to America in 1850 , becoming a successful lawyer in New York as well as a prominent historian and journalist who aroused public opinion against the mistreatment and exploitation of immigrants. Kapp, again like Solger, became active in the radical wing of the Republican party, winning the support of German-Americans for the Union cause. ${ }^{17}$

Around November 21 st or 22nd, Bakunin interrupted his stay in New York to visit Boston, where he remained a little over a week. It proved to be the high point of his sojourn in America. Armed with letters of introduction from Solger and Kapp, he called on a number of influential figures, among them the Governor of Massachusetts, John Andrew, a friend of Solger's and a radical Republican who had spoken out against slavery and raised funds for the defense of John Brown. Bakunin also carried letters to General George B. McClellan, Commander-in-Chief of the Union Army, who had visited Russia in 1855-56 as an observer of the Crimean War, and to both Massachusetts Senators, Charles Sumner and Henry Wilson, radical Republicans and abolitionists like Governor Andrew. A few years later, Bakunin was to praise Sumner, "the eminent Boston senator", for espousing a form of "socialism" by favoring the distribution of land among the freed slaves of the South. ${ }^{18}$

15 Ibid., p. 467; Dictionary of American Biography, XVII, pp. 393-94. See also The Forty-Eighters: Political Refugees of the German Revolution of 1848, ed. by A. E. Zucker (New York, 1950), pp. 124, 343-44; Carl Wittke, Refugees of Revolution: The German Forty-Eighters in America (Philadelphia, 1952), pp. 310-11.

16 When Bakunin visited Solger's New York home, he wrote a note to Herzen and Ogarev, to which Solger and Kapp appended their greetings. See Bakunin to Herzen and Ogarev, December 3, 1861, Pis'ma, p. 193.

17 The Forty-Eighters, op. cit., pp. 307-08; Wittke, Refugees of Revolution, op. cit., pp. 43, 62-63. See also Edith Lenel, Friedrich Kapp (Leipzig, 1935).

18 M. Bakunin, Oeuvres (6 vols; Paris, 1895-1913), I, p. 50. On Sumner see the fine two-volume biography by David H. Donald, Charles Sumner and the Coming of the Civil War and Charles Sumner and the Rights of Man (New York, 1960-70). 
Sumner's colleague, Henry Wilson, was a former shoemaker who had risen from poverty to the position of Senator and, a decade later, of Vice President of the United States under Ulysses S. Grant. A labor reformer as well as an abolitionist, his sympathies were always with the workingmen from whose ranks he had sprung (in 1858 he addressed the Senate on the question "Are Working-Men 'Slaves"?"). He was best known, however, for his championship of the anti-slavery cause, speaking before the Senate on "Aggressions of the Slave Power" and "The Death of Slavery Is the Life of the Nation", and later publishing a three-volume History of the Rise and Fall of the Slave Power in America (1872-77).$^{19}$ Bakunin also called on George H. Snelling, a Boston reformer who, like Bakunin himself, was an avid partisan of Polish emancipation and the translator of a history of the Polish insurrection of $1830-31 .{ }^{20}$ Bakunin thus took special pleasure in making his acquaintance, and "at their first meeting he embraced him with much warmth", a contemporary recalls. ${ }^{21}$

Bakunin, in short, mingled with the leading lights of progressive Boston society. Politicians and generals, businessmen and writers, they were men of liberal temperament and advanced social and political views who favored the growth of democracy and national independence in Europe. As abolitionists and reformers they were conscious of the parallel between the freeing of the serfs in Russia and their own anti-slavery crusade, and among them Bakunin found a great sympathy for the Russian people in their continuing struggle against autocracy.

One such reformer was Martin P. Kennard, an abolitionist and partner in a Boston jewelry firm, to whom Solger had given Bakunin a letter of introduction. ${ }^{22}$ Bakunin dined twice at Kennard's home in Brookline and visited his office in Boston. Kennard describes his guest as "a large heavily framed yet well proportioned man, more than six feet in height, in bearing noble, in personage genial and attractive, and well-nigh entirely enveloped in a rubber Mackintosh". Bakunin, who amusingly called himself a "Russian bear", found in Kennard a sympathetic listener. As Oscar Handlin notes, Kennard's progressive convictions, which had drawn him into societies to protect runaway slaves, reflected a broader concern for

19 On Wilson see Richard H. Abbott, Cobbler in Congress: The Life of Henry Wilson, 1812-1875 (Lexington, Ky, 1972); Dictionary of American Biography, XX, pp. 322-25.

20 Józef Hordyński, History of the Late Polish Revolution, and the Events of the Campaign (Boston, 1832).

21 Martin P. Kennard, "Michel Bakounin", manuscript in Harvard Library, published by Oscar Handlin, "A Russian Anarchist Visits Boston", in: The New England Quarterly, XV (1942), pp. 104-09.

${ }^{22}$ Kennard describes Solger as "a valued friend" who, like Bakunin, "had been compelled to flee, a political refugee from the absolutism of his fatherland". Ibid., p. 105. 
human freedom, in Europe as well as America. At their first meeting, Bakunin told Kennard "of the struggle for the life of Poland, the unification of Germany, and of the republican movement throughout Europe, and of its temporary failure". As Bakunin spoke, it was clear to his host that "his courage was still undaunted, and his ardor in no wise abated". ${ }^{23}$

One day, while Bakunin was visiting Kennard at his Boston firm, an Austrian officer, preparing to enter service in a Massachusetts unit of the Northern Army, happened to be in another room. Kennard's partner, $\mathrm{Mr}$ Bigelow, asked him if he had ever heard of Bakunin. “'Yes!' was the prompt reply" according to Kennard's account, "'but what do you know of Bakounin?' 'He is sitting there in the Counting Room', was the response. 'Oh no!' replied this officer, with decided positiveness, 'it is impossible. He was exiled to Siberia for life, and it was reported long since that he is dead. Any one here who claims to be Michel Bakounin is an imposter.' 'The door is open; he sits there in plain sight; if you have ever seen him, go and see if you can now recognize him', said my partner. The officer deliberately strolled past the open door and glanced at our stranger. 'Sure enough', said he returning to his interlocutor in excited amazement, 'that is Bakounin! Pray how came he here (I omit his expletives) tell me all about this. Such a thing never occurred before.' 'He has just escaped from Siberia', rejoined my partner. 'Now tell me what you know of him.' 'Well', said the officer, 'when Bakounin was tried and sentenced to death, I was there in the service, and the orders were given to me to take him from the Court House with a mounted guard of soldiers, and conduct him to the prison. I took charge of him, I saw him placed in the carriage and the door fastened upon him, and I rode by its side and delivered him within the prison gates.' There is ample opportunity here to comment upon the limitations of the area [of] this world as well as to philosophize upon this strange meeting of these two men of such divergent and exceptional experience, and after so many years, and under such unusual circumstances; but I forbear, and must leave these reflections to my auditors."24

Like Kennard and his other hosts, Bakunin was firmly opposed to Negro slavery, indeed to slavery in all its manifestations. Throughout his sojourn in America, he moved in abolitionist circles, defended the anti-slavery movement and, unlike Proudhon, supported the Union in the struggle between the states. The Civil War "interests me in the highest degree", he wrote to Herzen and Ogarev from San Francisco. "My sympathies are all with the North". ${ }^{25}$ So strong were his feelings on the slavery issue that had

23 Ibid., p. 107.

24 Ibid., pp. 107-08.

25 Pis'ma, p. 190. 
circumstances permitted, according to Kennard, "he would have cast his future fortune with Americans and heartily joined in the events of the War." ${ }^{6}$ In later years he condemned the Northern apologists of slavery, along with "the ferocious oligarchy" of Southern planters, as being "demagogues without faith or conscience, capable of sacrificing everything to their greed, to their malignant ambition". Such men, he said, had "greatly contributed to the corruption of political morality in North America". 27

Not that the South was totally devoid of merit. No less than Proudhon, Bakunin distrusted the growing centralization of Union power and cherished the waning agrarian virtues of the Confederacy, whose political structure he considered in some ways freer and more democratic than that of the North. ${ }^{28}$ In reaching this conclusion, we learn from Kennard, Bakunin was probably influenced by Senator Gwin, "whose acquaintance he had made on his voyage from San Francisco via Panama, and who has sometimes been mentioned in the newspapers as 'Duke Gwin"'.29 Southern federalism, however, Bakunin was quick to point out, had been tarnished by the "black spot" of slavery, with the result that the Confederate states had "drawn upon themselves the condemnation of all friends of freedom and humanity". Moreover, with "the iniquitous and dishonorable war which they fomented against the republican states of the North, they nearly overthrew and destroyed the finest political organization that ever existed in history". ${ }^{30}$

Soon after arriving in Boston, Bakunin went to Cambridge to visit his "old friend" Louis Agassiz, ${ }^{31}$ the famous Swiss naturalist, whom he had met at Neuchâtel in 1843. Agassiz had emigrated to the United States in 1846 and was now Professor of Zoology at Harvard and a friend of Henry Wadsworth Longfellow, to whom he gave Bakunin a letter of introduction. Longfellow, a man of abolitionist sympathies, was well known, apart from his other writings, for his Poems on Slavery; and when Bakunin dined at Craigie House, Longfellow's Cambridge home, George Sumner, a brother of the abolitionist Senator, was also invited. The date was November 27th and, according to Van Wyck Brooks, Bakunin arrived at noon and stayed till almost midnight. ${ }^{32}$ Longfellow recorded the occasion in his diary:

26 Handlin, “A Russian Anarchist”, loc. cit., p. 108.

27 Bakunin, Oeuvres, I, p. 172.

28 Ibid., pp. 21-22.

29 Handlin, "A Russian Anarchist", p. 107.

30 Bakunin, Oeuvres, I. p. 22.

31 Pis'ma, p. 190.

32 Van Wyck Brooks, The Flowering of New England, 1815-1865, revised ed. (New York, 1937), p. 510. 
"George Sumner and Mr. Bakounin to dinner. Mr. B. is a Russian gentleman of education and ability - a giant of a man, with a most ardent, seething temperament. He was in the Revolution of Forty-eight; has seen the inside of prisons - of Olmütz, even, where he had Lafayette's room. Was afterwards four years in Siberia; whence he escaped in June last, down the Amoor, and then in an American vessel by way of Japan to California, and across the isthmus, hitherward. An interesting man." 33

Bakunin had read some American literature, including the works of James Fenimore Cooper in German translation, and had studied English while in prison, so that he could speak it, says Kennard, "with fair facility". ${ }^{34}$ Despite his years of confinement, he still possessed much of his old vitality and exuberance. He had aged, to be sure, had lost his teeth from scurvy and grown quite fat. But the grey-blue eyes retained their penetrating brilliance; and his voice, his eloquence, his physical bulk combined to make him the center of attention. He was, moreover, a nobleman as well as a rebel, endowed, as E. H. Carr has noted, with the kind of aristocratic temperament which dissolved all barriers of class, enabling him to move with ease among men of different social and national background. "Without the least reserve", writes Kennard in this connection, "my new acquaintance made himself at once on good terms, and in a free and easy manner rendered himself agreeable, with a cosmopolitan complaisance that bespoke an intelligent and affable gentleman, and energetic man of affairs." 35

Wherever he went Bakunin exerted a powerful fascination, making a favorable impression on nearly everyone he met. In after years, says Kennard, Longfellow "regularly enquired for the latest news of his radical guest, and of whom he related to me some amusing incidents". ${ }^{36}$ The sole dissenter, it seems, was Longfellow's youngest daughter Annie, the "laughing Allegra" of The Children's Hour, who left an amusing memoir of Bakunin's visit. When she came down to dinner she saw an "ogre" in her customary seat beside her father, a "big creature with a big head, wild bushy hair, big eyes, big mouth, a big voice and still bigger laugh". She had not been brought up on Grimm's Fairy Tales for nothing, she writes. "No entreaties or persuasion could induce me to cross the threshold of that door. I stood petrified and while I resented his having my place at table,

${ }^{33}$ Life of Henry Wadsworth Longfellow, ed. by Samuel Longfellow ( 3 vols; Boston, 1886), II. p. 371 .

${ }^{34}$ Handlin, "A Russian Anarchist", p. 107. Contrast Carr, Michael Bakunin, p. 261:

"Bakunin never acquired more than a smattering of spoken English".

${ }^{35}$ Carr, Michael Bakunin, pp. 251-55; Handlin, "A Russian Anarchist", p. 105.

36 Handlin, "A Russian Anarchist”, p. 106. 
what was dinner to me as long as he didn't make his dinner off me. So I vanished dinnerless." 37

At the beginning of December, Bakunin returned from Boston to New York. With letters of recommendation obtained in these cities, he had intended to go on to Washington, as he told Herzen and Ogarev, and possibly "learn something" there. ${ }^{38} \mathrm{E}$. H. Carr writes that it is not known whether he made the trip. From Kennard, however, we learn that he did not, owing to "a constant anxiety and characteristic impatience to depart to London, where it had been arranged he should rendesvous [sic] to meet his wife, of whom he often spoke with the tenderest affection". ${ }^{39}$ Thus, when money arrived from England, Bakunin booked passage on the earliest ship, the City of Baltimore, which sailed for Liverpool on December 14th. ${ }^{40}$ Arriving on the 27 th, he went directly to London, where, greeted by Herzen and Ogarev "as a brother", ${ }^{41}$ he rejoined the revolutionary movement.

What impression of the United States did Bakunin carry away with him? On the whole it was a favorable one, but with serious reservations about the country's political and social character. "I spent over a month in America and learned a great deal", he wrote to a Russian friend in February 1862. "I saw how the country has been brought by demagogy to the same miserable results which we have achieved by despotism. Between America and Russia, in fact, there is much in common. But most important to me, I found in America such universal and unconditional sympathy for Russia and faith in the future of the Russian people that, in spite of all that I saw and heard there, I left America a strong partisan of the United States." 42

Beyond this sympathy for Russia, what impressed Bakunin most about America was its history of political liberty and its federalist system of government. Extolling the American Revolution as "the cause of liberty against despotism", he was "very anxious to possess, as a souvenir of his visit to America, an autograph of Washington", with which Martin Ken-

37 Annie Longfellow Thorp, "A Little Person's Little Memories of Great People", Longfellow Papers, Craigie House, Cambridge, published by David Hecht, "'Laughing Allegra' Meets an Ogre", in: The New England Quarterly, XIX (1946), pp. 243-44.

38 Pis'ma, pp. 190-91.

39 Carr, Michael Bakunin, p. 247; Handlin, “A Russian Anarchist”, p. 107.

40 Nettlau, Michael Bakunin, op. cit., I, pp. 138-40; The New York Times, December 15, 1861.

41 Bakunin, "Herzen", in Archives Bakounine, ed. by Arthur Lehning, V (Leiden, 1974), p. 23.

42 Bakunin to P. P. Lialin, London, February 27, 1862, in M. K. Lemke, Ocherki osvoboditel'nogo dvizheniia "shestidesiatykh godov" (St Petersburg, 1908), pp. 134-35. 
nard was able to present him as a parting token. ${ }^{43}$ In his future writings, he would characterize the United States as "the classic land of political liberty", the freest country in the world endowed with "the most democratic institutions". ${ }^{44}$ American federalism left a particularly deep impression, enriching his own ideas on the subject. To European progressives he warmly recommended "the great and salutary principle of federalism" as embodied in the United States. "We must reject [the] politics of the State", he told the League of Peace and Freedom in 1868, "and adopt resolutely the politics of liberty of the North Americans." 45

In spite of his anarchist doctrines, which matured over the next few years, Bakunin did not lump all governments together as equally wicked and oppressive. From his personal experience in America, and afterwards in England and Switzerland, he was convinced that "the most imperfect republic is a thousand times better than the most enlightened monarchy". ${ }^{46}$ The United States and Britain, he remarked, were "the only two great countries" where the people possessed genuine "liberty and political power", and where even "the most disinherited and miserable foreigners" enjoyed civil rights "as fully as the richest and most influential citizens" ${ }^{47}$ In both of these countries, of course, he himself had found political asylum; moreover, the United States government, during his visit, had refused to extradite him, which convinced the Russian ambassador, Baron Stoeckel, that the American republic would never cease "to protect revolutionists". ${ }^{48}$ While in Boston, interestingly enough, Bakunin made a primary declaration of American citizenship, the equivalent of taking out his "first papers". "He probably never entertained a serious thought of ever becoming an American citizen", noted Martin Kennard, "and yet, with some vague idea of such a possibility or of some remote advantage to himself, he made and duly recorded in Boston his primary declaration of such intention." And in the last years of his life, while living in Switzerland, he again spoke of emigrating to America and becoming naturalized there. ${ }^{49}$

Looking back to his American sojourn, Bakunin recalled a society in which workingmen never starved and were "better paid" than their

43 Bakunin, Oeuvres, IV, p. 289; Handlin, "A Russian Anarchist”, p. 109.

44 Bakunin, Oeuvres, I, p. 171.

45 Ibid., pp. 12-13. See also Hans Rogger, "Russia and the Civil War", in: Heard Round the World, ed. by Harold Hyman (New York, 1969), pp. 177-256.

46 Bakunin, Oeuvres, I, p. 174.

47 Ibid., IV, p. 448.

48 Quoted in Max M. Laserson, The American Impact on Russia: Diplomatic and Ideological, 1789-1917 (New York, 1950), p. 171.

49 Handlin, "A Russian Anarchist", p. 108; Carr, Michael Bakunin, p. 491. 
European counterparts. "Class antagonism", he wrote, "hardly yet exists", for "all workers are citizens", part of a "single body politic", and education is "widespread among the masses". These benefits, he said, were rooted in the "traditional spirit of liberty" which the first colonists had imported from England and, along with the principle of "individual independence and communal and provincial selfgovernment" (in English), had transplanted into a wilderness that was free from "the obsessions of the past". In less than a century, therefore, America had been able "to equal and even surpass the civilization of Europe" and to offer "a freedom which does not exist anywhere else". 50

According to Bakunin, America owed its "marvelous progress" and "enviable prosperity" to its "immense reaches of fertile land", its "great territorial wealth". Because of this abundance, he said, hundreds of thousands of settlers were being absorbed every year, and an unemployed or ill-paid worker could, as a last resort, "always migrate to the far west" (in English) and set about clearing a stretch of land for cultivation. ${ }^{51}$ To some extent, perhaps, Bakunin's image of the American wilderness was shaped by the stories of Fenimore Cooper; and there were moments, particularly in prison, when he himself longed for the life of a Western mountaineer. His Confession to Nicholas I, written in the Peter-Paul fortress in 1851, contains a striking passage to this effect: "In my nature there has always been a basic flaw: a love for the fantastic, for unusual, unheard-of adventures, for undertakings that open up vast horizons, the end of which cannot be foreseen. [...] Most men seek tranquillity, which they consider the highest blessing. In me, however, it produces only despair. My spirit is in constant turmoil, demanding action, movement and life. I should have been born somewhere in the American forests, among the settlers of the West, where civilization has hardly begun to blossom and where life is an endless struggle against untamed peoples, against untamed nature, and not in an organized civic society. And if fate had in my youth made me a sailor, I would probably now be a respectable person, without any thought of politics and seeking no other adventures and storms but those of the sea." 52

Bakunin, however, was not without criticism of America. On the day of his arrival in San Francisco, he already complained to Herzen and Ogarev

50 Bakunin, Oeuvres, I, pp. 28-30. Bakunin's esteem for local self-government was influenced, among others, by Proudhon, Tocqueville and John Stuart Mill.

51 Ibid., pp. 28-29. This, as David Hecht points out in Russian Radicals Look to America, 1825-1894 (Cambridge, Mass., 1947), pp. 58-60, was written twenty-five years before Frederick Jackson Turner enunciated his famous "safety-valve" theory of American social stability.

52 Bakunin, "Ispoved"', Sobranie sochinenii i pisem, IV, pp. 154-55. 
of the "banality of soulless material prosperity" and the "infantile national vanity" that he found in the United States. The Civil War, he thought, might save America and restore its "lost soul". 53 "He used to assert", writes Martin Kennard, "that after the War, America would become a great power, more individualized, so to speak, and better poised in her social life, and that her great trial could bring out great men, indeed greater than she had ever known." ${ }^{4}$ Yet America's favored position was only temporary, Bakunin believed. For recent years had seen the crowding together in such cities as New York, Philadelphia and Boston of "masses of proletarian workers", who were beginning to find themselves in a condition "analogous to that of workers in the great manufacturing states of Europe". As a result, "we see in fact the social question confronting the Northern states just as it confronted us much earlier." 55 Before long, the American laborer would be no better off than his European counterpart, the victim of rapacious capitalism and of centralized political power. No state, Bakunin insisted, however democratic, could get along without "the forced labor of the masses", which was "absolutely necessary for the leisure, liberty, and civilization of the political classes: the citizens. On this point, not even the United States of North America can as yet form an exception."56

Although Bakunin continued to prefer the democratic system of the United States, England and Switzerland to the despotism of most other countries, his criticism of government in general mounted as the years advanced. "What do we really see in all states, past and present, even those endowed with the most democratic institutions, such as the United States of North America and Switzerland?" he asked in 1867. "The self-government of the masses, despite the pretense that the people hold all the power, remains a fiction most of the time." Representative government, he added, benefits only the wealthy classes, and universal suffrage is merely a tool of the bourgeoisie, while the masses are "sovereign in law, not in fact". For "ambitious minorities", the "seekers of political power", attain predominance "by wooing the people, by pandering to their fickle passions, which at times can be quite evil, and, in most cases, by deceiving them". While preferring a republic, therefore, "we must nevertheless recognize and proclaim that whatever the form of government may be, so long as human society continues to be divided into different classes as a result of hereditary inequality of occupation, wealth, education and rights, there will

53 Pis'ma, p. 190.

54 Handlin, "A Russian Anarchist", p. 108.

55 Bakunin, Oeuvres, I, pp. 29-30.

56 Ibid., pp. 157-58. 
always be a class-restricted government and the inevitable exploitation of the majority by the minority." 57

These themes are often repeated in Bakunin's subsequent writings. In God and the State, drafted in 1871, he stresses that even parliamentary regimes elected by universal suffrage quickly degenerate into "a sort of political aristocracy or oligarchy. Witness the United States of America and Switzerland." 58 In The Knouto-Germanic Empire and the Social Revolution, an unfinished work of which God and the State is a fragment, he re-emphasizes that even "in the most democratic lands, such as the United States of America and Switzerland", the state represents an instrument of "minority privilege and the practical subjugation of the vast majority". ${ }^{59}$ And again in Statehood and Anarchy, published in 1873, he writes that in the United States "a special, thoroughly bourgeois class of so-called politicians or political dealers manages all affairs, while the masses of workers live under conditions just as cramped and wretched as in monarchic states". 60

During the last years of his life, Bakunin despaired of any immediate improvement. To Elisée Reclus, the French geographer and anarchist, he wrote in 1875 that "evil has triumphed" everywhere, what with the restoration of the Spanish monarchy, Bismarck at the helm of a rising German state, the Catholic church still rich and powerful over a vast part of the world, England faltering, Europe as a whole degenerating, "and farther away the model republic of the United States of America coquetting already with military dictatorship. Poor humanity!" The only escape from this "sewer", as Bakunin termed it, was by "an immense social revolution", which could erupt only during a world war. "Sooner or later", he said, "these enormous military states will have to destroy and devour each other. But what a prospect!"61

\section{III}

During his brief visit to the United States, Bakunin left no discernible imprint on the revolutionary and working-class movements, which were in

57 Ibid., pp. 171-74.

${ }^{58}$ M. Bakunin, God and the State (New York, 1970), p. 32.

59 Bakunin, Oeuvres. I, pp. 287-89.

60 Archives Bakounine, III (Leiden, 1967), p. 45. On another occasion, while praising educational advances in America and Switzerland, Bakunin nevertheless argued that "children of the bourgeoisie" enjoyed a higher education while those "of the people" received a "primary education only, and on rare occasions a bit of secondary education". Oeuvres, V, p. 324.

61 Bakunin to Reclus, Lugano, February 15, 1875. in: James Guillaume, L'Internationale: documents et souvenirs (1864-1878) (4 vols; Paris, 1905-10), III, pp. 284-85. 
an embryonic phase of development. The International Working Men's Association, for example, was not founded until 1864, and its first American section was formed only in 1867. Bakunin himself did not become a member of the International until 1868 , after which, however, his influence spread rapidly. By the early 1870 's, at the height of his conflict with Marx, he could count on substantial support within the American branch of the International, which was far from being an exclusively Marxist organization, as historians sometimes portray it.

Between 1870 and 1872 , federalist sections of the International were established in New York, Boston and other American cities. In New York, for example, Sections 9 and 12 were organized by such prominent libertarians as William West, Victoria Woodhull, her sister Tennessee Claflin, and Stephen Pearl Andrews, who hailed Bakunin as "a profound thinker, an original genius, a scholar and a philosopher". ${ }^{62}$ William B. Greene, the leading American disciple of Proudhon, helped start a libertarian section of the International in Boston, while his colleague Ezra Heywood addressed Internationalist meetings in New York and other cities. In 1872, moreover, Heywood launched a monthly magazine, The Word, in Princeton, Massachusetts, one of the first American journals to publish Bakunin's writings. ${ }^{63}$ Together with Woodhull \& Claflin's Weekly in New York, The Word became the unofficial organ of the International's libertarian wing in the United States, defending the principles of decentralist socialism and criticizing the Marxist-controlled General Council for its authoritarian orientation. "It is not pleasant to see Dr. Marx and other leaders of this great and growing fraternity lean so strongly towards compulsory politics", declared The Word in May 1872. "Let us be governed by the laws of nature until we can make better. If the International would succeed it must be true to its bottom idea - voluntary association in behalf of our common humanity." ${ }^{64}$. In addition to the native American groups, a number of foreign-language (principally French) sections of the International in America adhered to the Bakuninist rather than the Marxist wing. These included Section 2 of New York (composed in part of refugees from the Paris Commune), Section 29 of Hoboken, New Jersey, and Section 42 of Paterson, New Jersey, a city soon to emerge as a major anarchist

${ }^{62}$ Quoted by Charles Shively, introduction to S. P. Andrews, The Science of Society (Weston. Mass., 1970, reprint of the Benjamin Tucker edition of 1888), p. 21.

${ }^{63}$ See, for example, Bakunin, "Gospel of Nihilism", in: The Word, April 1880.

${ }_{64}$ As one might expect, Marxist and other non-anarchist journals portrayed Bakunin in an unfavorable light. For example, the New York Arbeiter-Union of October 20, 1869, called him an "agent-provocateur in the service of Russia and of panslavism". See Archives Bakounine, V, pp. 564-66. 
stronghold. Bakunin found additional adherents within the Icarian community at Corning, Iowa, where his portrait decorated the common room. ${ }^{65}$

In spite of Bakunin's expulsion from the International in 1872, his influence continued to grow on both sides of the Atlantic. Nor did it decline after his death in 1876. During the 1880's, on the contrary, his writings began to be published in the United States, making a powerful impression on the emerging anarchist and socialist movements. It was a young New England anarchist named Benjamin R. Tucker who did the most to publicize Bakunin's ideas in North America. In 1872 Tucker was an eighteen-year-old student at the Massachusetts Institute of Technology when he attended his first anarchist meeting in Boston. There he met Ezra Heywood, William Greene and Josiah Warren (the "father" of American anarchism), who impressed him so favorably that he became a lifelong convert to their cause. After serving as associate editor of The Word during the mid 1870's, Tucker founded his own journal, Liberty, which ran from 1881 to 1908 , superseding The Word as the principal organ of individualist anarchism in the United States.

Like Bakunin's Boston hosts of twenty years before, Tucker had great sympathy for the Russian people and the Russian revolutionary movement. In the first issue of Liberty (August 8,1881 ) page one displayed a portrait of Sophia Perovskaya, who earlier that year had been hanged for her part in the assassination of Alexander II. Beneath the portrait was a moving poem by Joaquin Miller, "Sophie Perovskaya, Liberty's Martyred Heroine, Hanged April 15, 1881, For Helping to Rid the World of a Tyrant". In the same number, Tucker hailed Perovskaya's associate Lev Hartmann, who had come to America as an envoy of the People's Will, as "a fine writer, an heroic worker, a grand man". Succeeding issues of Liberty contained news of Russian revolutionists exiled in Western Europe or banished to Siberia by Alexander III. In addition to Perovskaya, Tucker praised such "remarkable types of Nihilist women" as Vera Zasulich, Vera Figner and Sophia Bardina. In January 1882 he printed an appeal of the Red Cross Society of the People's Will, signed by Zasulich and Peter Lavrov, who, said Tucker, "speak authoritatively for the best elements of Russian life". ${ }^{66} \mathrm{He}$ himself became the Society's American representative and took up a collection in Liberty, forwarding the proceeds to Nicholas Chaikovsky in London.

65 Socialism and American Life, ed. by Donald Drew Egbert and Stow Persons (2 vols; Princeton, 1952), I, p. 207.

66 Liberty, January 7 and 21, March 18, 1882. 
Apart from Bakunin, Tucker published such well-known Populists and revolutionaries as Chernyshevsky and Tolstoy, Kropotkin and Stepniak, Korolenko and Gorky. It was Tucker who (working from a French edition as he lacked any knowledge of Russian) produced the first English translation of Chernyshevky's What Is To Be Done?, calling the author a "martyr-hero of the modern Revolution". ${ }^{67}$ In 1890 Tucker published The Kreutzer Sonata by Tolstoy, which he again rendered from the French, as well as a review of the book by N. K. Mikhailovsky, translated from the Russian by Victor S. Yarros (Yaroslavsky), a former Narodnik from Kiev who was Liberty's associate editor. ${ }^{68}$ Beyond all this, Tucker translated two of Peter Kropotkin's best-known essays, "Order and Anarchy" and "Law and Authority", from the Swiss journal Le Révolté. He also printed news of Kropotkin's expulsion from Switzerland in 1881 and of his trial at Lyons in 1883 (lamenting the "cruel fate of Kropotkine and his comrades", sentenced to long terms of imprisonment) and published Sophia Kropotkin's "The Wife of Number 4,237" (translated from the French by Sarah E. Holmes, a contributor to Liberty), based on her own experience with her husband at Clairvaux Prison. ${ }^{69}$ Tucker, moreover, called on Kropotkin when the anarchist prince came to the United States on a lecture tour in 1897.

The first mention of Bakunin in Liberty's columns occurred on November 12, 1881, when Tucker announced that he had obtained a photograph of "the great revolutionist", which he offered for sale at fifty cents a copy. Two weeks later, an engraving of the picture appeared on the front page of Liberty, captioned "Michael Bakounine: Russian Revolutionist, Father of Nihilism, and Apostle of Anarchy". This was accompanied by a biographical sketch of Bakunin compiled by Tucker from French and German sources. ${ }^{70}$ Of Bakunin Tucker wrote: "We are willing to hazard the judgment that coming history will yet place him in the

${ }^{67}$ Serialized in Liberty, May 17, 1884, and following issues, published in book form in 1886. The most recent edition of the Tucker translation was published by Vintage Books of New York in 1961, revised and abridged by Ludmilla B. Turkevich.

68 Liberty, June 7, 1890. Yarros also wrote essays for Liberty on Chernyshevsky and Herzen.

69 Ibid., October 29, 1881; June, 1882, and following issues; February 17, 1883; March 6, 1886, and following issues.

${ }^{70}$ Ibid., November 26, 1881. Tucker's sources probably included J. W. A. von Eckardt, Russia Before and After the War, transl. by Edward Fairfax Taylor (London and Boston, 1880 ), with a 48-page chapter on Bakunin; and an article on Bakunin by $E$. de Laveleye in the Revue des Deux Mondes of the same year. In 1908, it might be added, Tucker published an American edition of Paul Eltzbacher's Anarchism (translated from the German by Tucker's associate Steven T. Byington), which contains a valuable chapter on Bakunin and his ideas. 
very front ranks of the world's great social saviours. The grand head and face speak for themselves regarding the immense energy, lofty character, and innate nobility of the man. We should have esteemed it among the chief honors of our life to have known him personally, and should account it a great piece of good fortune to talk with one who was personally intimate with him and the essence and full meaning of his thought and aspiration." 71

Tucker's greatest contribution towards familiarizing the American reading public with Bakunin was his translation of God and the State, Bakunin's most famous work. The original French edition appeared in 1882, with a preface by two of Bakunin's most devoted disciples, Carlo Cafiero and Elisée Reclus. Tucker began selling it (at twenty cents a copy) as soon as he received a shipment from Geneva. Scarcely a year later, in September 1883, he published his English translation, including the Cafiero and Reclus preface. ${ }^{72}$ The booklet had an excellent sale and went through at least ten printings, becoming the most widely read and frequently quoted of all Bakunin's works, a distinction which, nearly a century later, it still enjoys. ${ }^{73}$. In the midst of his translation of God and the State, Tucker learned that another Boston anarchist named Marie Le Compte (of French origin, she styled herself "Miss Le Compte, Prolétaire") was preparing an independent translation in Bern, Switzerland, where Bakunin is buried. ${ }^{74}$ Miss Le Compte's rendition was serialized in the undermentioned Truth in 1883 and $1884,{ }^{75}$ but it was Tucker's translation that became the standard English version, reappearing in several editions, both in Britain and the United States, over the ensuing decades. ${ }^{76}$ Tucker, furthermore, published another important work of

71 Liberty, November 26, 1881.

72 Ibid., July 22, 1882; Tucker to Joseph A. Labadie, September 18, 1883, Labadie Collection, University of Michigan.

${ }^{73}$ A leading authority on Tucker calls its publication "a landmark in anarchist propaganda". James J. Martin, Men Against the State: The Expositors of Individualist Anarchism in America, 1827-1908, revised ed. (Colorado Springs, Colo., 1970), p. 219.

${ }^{74}$ See her letter to Tucker of July 4, 1883, in Liberty, August 25, 1883.

75 Truth, September 8, 1883 - January 19, 1884. She also published a translation of Kropotkin's "To Young People" (An Appeal to the Young) in Truth, January 5 January 26, 1884.

${ }^{76}$ In the United States it was re-issued in 1896 by E. H. Fulton of Columbus Junction, Iowa, as Liberty Library No 2; in 1900 by Abe Isaak (a Russian Mennonite turned anarchist) of San Francisco, as Free Society Library No 4; and in 1916 (as amended by Max Nettlau) by Emma Goldman's Mother Earth Publishing Association, which incorrectly labeled it the "first American edition". Much to Tucker's consternation, the Liberty Library and Free Society editions failed to credit him with the translation, erroneously attributing it to Cafiero and Reclus, who had merely contributed the foreword. 
Bakunin's, The Political Theology of Mazzini and the International, translated from the French by Sarah E. Holmes and serialized in Liberty in 1886 and $1887 .{ }^{77}$

That an individualist and "philosophical" anarchist like Tucker should have been the chief American expositor of Bakunin, himself an apostle of collectivism and revolution, stems from their common devotion to freedom and rejection of coercive authority, whether religious or secular, economic or political. Not surprisingly, however, Bakunin won his principal following in America among those who, unlike the Tuckerite school, shared his revolutionary and communalist convictions. An example was the group around The An-archist, a "Socialistic Revolutionary Review" published by Edward Nathan Ganz in Boston in 1881, of which only two issues were printed, the second being suppressed by the police. Another case in point was the San Francisco Truth ("A Journal for the Poor"), organ of the International Workmen's Association founded by Burnette G. Haskell. Even more, the spirit of Bakunin pervaded the Chicago Alarm, with its special concern for the disinherited and unemployed. Edited by Albert R. Parsons, the Haymarket martyr, The Alarm sold copies of God and the State (and of Stepniak's Underground Russia) and printed extracts from the Bakunin/Nechaev Catechism of a Revolutionary. ${ }^{78}$ Still another militant journal with a strong Bakuninist flavor was the New York Solidarity, which appeared in the 1890's. Its editor, John H. Edelmann, an architect by profession and host to Kropotkin during his 1897 visit, had become an anarchist after studying Bakunin, "whose memory he revered".79

With the influx of immigrants during the late nineteenth and early twentieth centuries, the revolutionary anarchist movement received a fresh supply of recruits. Beginning in the 1880's, Bakunin's writings were translated into a number of European languages - German, Czech, Russian, Yiddish, Italian, Spanish - by newly formed anarchist groups. Here, again, God and the State was his most popular and widely distributed work. A German translation, by Moritz A. Bachmann, appeared in Philadelphia in 1884, barely a year after Tucker's English version, and was afterwards serialized in Johann Most's Freiheit, together with a long

77 Liberty, September 18, 1886 - June 18, 1887. Excerpts in Spanish appeared in the anarchist journal El Despertar (New York), June 1 and 15, 1892.

78 The Alarm, January 23, 1886. Although The Alarm attributes the Catechism to Bakunin alone, most modern scholars regard Nechaev as the principal and perhaps the sole author.

${ }_{79}$ Freedom (London), September-October 1900. In 1901, to mention another example, Abe Isaak's Free Society appealed for funds to decorate and maintain Bakunin's grave. Free Society (Chicago), August 4, 1901. 
biographical article on Bakunin. ${ }^{80}$ In due time, Czech, Russian and Yiddish editions likewise made their appearance, ${ }^{81}$ while other writings by Bakunin cropped up in a whole range of anarchist journals in different languages and locations. ${ }^{82}$

Bakunin, it goes without saying, exerted a particularly strong influence on the Russian anarchist movement that emerged in North America after the turn of the century. Speakers for the Anarchist Red Cross and the Union of Russian Workers in the United States and Canada were active in spreading Bakunin's doctrines, while selections from his writings appeared in Golos Truda, the organ of the Union of Russian Workers, and in its successor, Khleb $i$ Volia, whose masthead displayed his famous dictum "The passion for destruction is also a creative passion." ${ }^{83}$ After the First World War, Bakunin's works were collected for publication in book form, but during the "Red Scare" hysteria of 1919-20 the Russian anarchist movement was broken up and its leaders imprisoned or deported, so that only the first of several projected volumes found its way into print. ${ }^{84}$

${ }^{80}$ M. Bakunin, Gott und der Staat (Verlag der Gruppe II, I.A.A., Philadelphia, 1884); Freiheit (New York), May 2 - June 13, 1891, then in pamphlet form as Internationale Bibliothek, No 17 (New York, 1892). Bakunin was often quoted by Most, the leading German anarchist in America, whose Pittsburgh Manifesto of October 1883 drew heavily on Bakuninist ideas.

${ }^{81}$ Dělnické Listy (New York), January 18, 1896, and following issues, reproduced in pamphlet form as Bủh a stát [Dělnicka Knihovna, No 4] (New York, 1896); Bog i gosudarstvo (Soiuz Russkikh Rabochikh gor. N'iu Iorka, New York, 1918); Fraye Arbeter Shtime, 1900-01.

82 For example, Freiheit, March 16 and April 6, 1895, printed a German translation of three lectures delivered by Bakunin in May 1871 at Courtelary in the Swiss Jura, re-issued as a pamphlet entitled Drei Vorträge. A Spanish translation appeared in El Esclavo of Tampa, Florida, in 1895, and a Czech translation in Dělnické Listy in 1895 and also as a pamphlet, Tři přédnáški [Dělnicka Knihovna, No 1] (New York, 1895). Bakunin's essays and speeches also appeared in such journals as Il Grido degli Oppressi (New York, 1892-94), Germinal (Paterson, 1899-1902), Volné Listy (New York, 1890-1917), Di Fraye Tsukunft (New York, 1915-16), Free Society (San Francisco, Chicago, New York, 1897-1904), Mother Earth (New York, 1906-17), and Why? (Tacoma, 1913-14).

${ }^{83}$ Golos Truda (New York, 1911-17); Khleb i Volia (New York, 1919). See also Rabochaia Mysl' (New York), August 1916, which invoked Bakunin and Herzen's slogan "To the People!" According to one authority, the first Russian paper in the United States, Svoboda, was published in California during the 1870's by a follower of Bakunin. L. Lipotkin [Lazarev], "Russkoe anarkhicheskoe dvizhenie v Severnoi Amerike: Istoricheskie ocherki”, manuscript, Internationaal Instituut voor Sociale Geschiedenis, p. 111 .

${ }_{84}$ M. Bakunin, Izbrannye sochineniia, I, with an introduction by Varlaam Cherkezov (Federatsia A.K.G. [Anarkho-Kommunisticheskikh Grupp], New York, 1920). See also Tak govoril Bakunin (Bridgeport, Conn., n.d. [1919?]), first published in Paris in 1914 by the Bratstvo Vol'nykh Obshchennikov. A Yiddish collection of Bakunin's writings, Geklibene shriften, was published in New York in 1919 by the Kropotkin Literary Society, with a biographical sketch by Rudolf Rocker. 
The years of the war and the decade preceding it constituted the last period for nearly half a century that Bakunin enjoyed a significant following in America. In that age of industrial ferment, Bakunin's notion that a free federation of trade unions would form "the living germs of the new social order, which is to replace the bourgeois world", ${ }^{85}$ made a deep impression on the Anarcho-Syndicalists and on the Industrial Workers of the World, founded in 1905 in Chicago. Inspired by similar ideas, a Bakunin Institute was established in 1913 near Oakland, California, by the Indian revolutionary Har Dayal. ${ }^{86}$ And in May 1914 the hundredth anniversary of Bakunin's birth was celebrated at Webster Hall in New York, where an audience of 2,000 heard eulogies by Alexander Berkman, Harry Kelly and Hippolyte Havel in English, Bill Shatoff in Russian, and Saul Yanovsky in Yiddish. ${ }^{87}$

But the anti-radical repressions during and after the war left the anarchists in disarray, inflicting a blow from which they never recovered. Languishing in prison, a celebrated victim of the Red Scare, Bartolomeo Vanzetti, pondered the similar fate of Bakunin: "Bakounin, a healthy giant such as he was - died at 62 years - killed by the prisons, the exile, and the struggle." 88 During the inter-war decades Bakunin's influence rapidly declined. While scattered excerpts from his writings continued to appear in anarchist publications - for instance, in The Road to Freedom and Vanguard of New York, and in Man! of San Francisco -, his books and pamphlets went out of print and became increasingly hard to come by. Gregory Maximoff, a refugee from the Bolshevik dictatorship, did more than anyone else to keep Bakunin's ideas alive, especially in Delo Truda and Delo Truda - Probuzhdenie, which he edited in Chicago and New York until his death in 1950 .

With the upsurge of the New Left in the 1960's, Bakunin had a conspicuous revival. Previously, American readers had to content themselves with Maximoff's posthumous compendium, The Political Philosophy of Bakunin (1953), and Eugene Pyziur's The Doctrine of Anarchism of Michael A. Bakunin (1955). Now, however, fresh anthologies and

${ }^{85}$ Quoted in Rudolf Rocker, Anarcho-Syndicalism (Indore, n.d.), p. 88.

${ }^{86}$ See Emily C. Brown, Har Dayal: Hindu Revolutionary and Rationalist (Tucson, Ariz., 1975), pp. 116-17

87 Mother Earth, May 1914; The Modern School, June 1, 1914. Havel produced a small pamphlet for the occasion, Bakunin, May 30, 1814 - July 1, 1876 (Centenary Commemoration Committee, New York, 1914. For a similar celebration in Paris, see Paul Avrich, The Russian Anarchists (Princeton, 1967), p. 114 and illustration 7.

${ }_{88}$ Vanzetti to Alice Stone Blackwell, September 15, 1925, The Letters of Sacco and Vanzetti, ed. by Marion Denman Frankfurter and Gardner Jackson (New York, 1928), p. 169. 
biographies appeared in print, ${ }^{89}$ and in campus demonstrations from Berkeley to Columbia the black flag of anarchy, inscribed with Bakuninist slogans, was once again unfurled. To the young radicals of the Vietnam era the "warfare state" seemed to be fulfilling Bakunin's most despairing predictions, while his formulas of self-determination and direct action exercised a growing appeal. Of particular relevance, after the lessons of Russia, Spain and China, was his message that social emancipation must be attained by libertarian rather than authoritarian methods, that socialism without liberty, as he put it, is the worst form of tyranny. In 1976, America's bicentennial year, anarchists in New York commemorated the hundredth anniversary of Bakunin's death, proclaiming the virtues of workers' selfmanagement, sexual liberation, equality of education and income, and the dispersal of state power. ${ }^{90}$ Similar gatherings took place in Zurich, Vienna and other cities around the world. To a new generation of rebels, a century after Bakunin's passing, his vision was as vital as ever.

89 For example, Bakunin on Anarchy, ed. by Sam Dolgoff (New York, 1972); M. Bakunin, Selected Writings, ed. by Arthur Lehning (New York, 1974); Daughter of a Revolutionary: Natalie Herzen and the Bakunin-Nechayev Circle, ed. by Michael Confino (LaSalle, Ill., 1974); Anthony Masters, Bakunin: The Father of Anarchism (New York, 1974). In 1961 E. H. Carr's Michael Bakunin was re-issued by Vintage Books of New York, and in 1970 Bakunin's God and the State, was reprinted - for the first time since the Mother Earth edition of 1916 - by Dover Publications of New York. The first English translation of Bakunin's Statehood and Anarchy appeared in New York in 1976, and his Confession was published in an English translation by Cornell University Press in 1977. See Paul Avrich, "Bakunin and His Writings", in: Canadian-American Slavic Studies, X (1976), pp. 591-96.

90 See Freedom (London), April 3, 1976. 